\title{
Stylistics Analysis of Russian Advertising Slogans
}

\author{
Yuli Angraini \\ English Department \\ University of Riau Kepulauan \\ angraini_yuli@yahoo.com
}

\begin{abstract}
The objectives of this study were (1) to describe types of stylistic features used in Russian advertisement slogan and (2) to interpret the writer's intention behind it. The method of the study was descriptive qualitative. The data was collected by using Russian advertisements consist of seven advertising slogans which taken from various of Russian advertisemens in internet. The data was analyzed by using stylistic analysis specifically by using stylistics features which limited in graphology, lexicology, syntax, grammar and semantics. From the analysis and interpretation, the stylistic features in Russian advertising slogan were clear and not ambiguous. They were conveyed the way they were. They knew their audiences well as it was shown from the advertisements above. Semantically, from one to seven advertisements, metaphor often appeared. From Lexicology, most of the words were easy to be interpreted by the consumers, only in the part of law advertisement was a bit difficult. Syntax that the advertising slogan used commonly in the form of declarative and imperative sentences. Grammar used in the advertisements contained suitable tenses with the moment shown in that ads.
\end{abstract}

Key Words: 1. Stylistic; 2. Russian Advertising Slogans

\section{INTRODUCTION}

One word can become the right way for someone to convey his or her intention to other people. On the other hand, one word that said by someone whether in one single letter such as "O" may express his or her thought directly or indirectly. It can lead to misinterpretation if the reader or the hearer cannot grasp what the speaker is actually trying to say as this example below:

Carla: "I am sick and very exhausted right now."

Bob: “O”.

Carla: What! We break up now! You do not care about me. You are so indifferent.

Bob: Are you crazy? Where is my fault? 


\section{Carla: U said 'O’.}

Bob: I said it because I got surprised! Learn about emoticon! Do not blame me for everything!

In that dialogue, the writer of the message-Bob said "O" because he got surprised that his girlfriend was sick. Meanwhile, Carla as "the reader" of Bob message" misinterpreted Bob's word as his indifference towards her condition that time. It happened because the various meaning of "O" itself. At a glance, that case looked trivial but it caused someone's life or behavior changed. The context created in that dialogue could be recognized easily by the reader's thought if the writer of the message said it in a real situation by face-to-face. The difference was it was written in the written text, that is, a message by using a telephone call or through internet without using video call. Therefore, reading is not just reading matter but also it involves many aspects.

One of the aspects of reading is the use of stylistic. Through stylistic, the words contain in the text can trigger the readers' feeling and reaction when they read it whether positively or negative one. Related to that, Simpson (2004) said to do stylistics is to explore creativity in language use. It can enrich ways of thinking about language and, as observed, exploring language offers a substantial purchase on the understanding of the texts. In other words, stylistics can make the readers of the text think beyond their mind to get what the writer tries to convey to them.

One of the example of reading text is in the form of advertisements from various style ranged between live ads around traffic light or just casual board on the streets. The message that the users of advertisement sell some remain simple but some others reflect the real situation faced by people in their life. Russian advertisement is one of them. If in commercial breaks, Russian ads tend to be more logical and straight to the point rather than western ones while in advertisement board or advertising slogans, Russian ads are closer to real life reflection whether it talks about political view, love or daily ones. However, this study was emphasized only in describing the use of linguistic stylistics in Russian advertising slogans and the interpretation of the literal meaning of that slogans. In the end, the significance of this study will broaden the readers' mind especially the students in interpreting something that looks superficial but needs closer attention and deep analysis further. 


\section{MATERIALS \\ DEFINITION OF SLOGAN}

Slogan, based on Business dictionary, is a simple and catchy phrase accompanying a logo or brand, that encapsulates a product's appeal or the mission of a firm and makes it more memorable and which (when used consistently over a long period), becomes an important component of its identification or image also called catch line, strap line, or tag line. In line with it, Newton said that a slogan is a catchy phrase or series of words used to help consumers remember a company, brand or product. Companies create slogans to use in various marketing efforts in hopes that the phrases will stick in people's minds. That way, when a consumer needs a product or service offered by a variety of companies, that consumer will choose the product or service that is top-of-mind from slogan recognition.

\section{WRITING A SLOGAN}

Slogans must be memorable. They must give people an idea of what your company or product does and must relate to your business in some way. Even though they consist of only a few words, slogans can take hours, sometimes much more, to write. Each word has to be perfect. If you are writing a slogan, look at your logo for ideas. Describe your logo and whittle the description to a few words. The slogan should match the feel of the logo, because they are often displayed together. Keep the slogan simple but memorable. Use rhyming or humor if appropriate to help people remember your slogan.

\section{SLOGAN WRITERS}

Not everyone can write a slogan. It is best to hire a professional writer to help with grammar and creative use of words. You can hire a copywriter, hire a freelance writer or use an advertising agency to come up with your next slogan. You can also ask for feedback or have brainstorming sessions with your employees. Some employees, including sales staff members, might be too close to the product or service to write an effective slogan, because their opinions and thoughts are biased. Slogans should be honest and not make false promises about your company or product, because that will only annoy and frustrate consumers. 


\section{SLOGAN EXAMPLE}

There are a number of good slogans that have been used in advertising. Many have been around for decades, and consumers immediately associate those slogans with a particular brand, company or product. For example, "Just do it" has been Nike's slogan for decades. Another example is Wheaties cereal's "Breakfast of champions" slogan, because it tells consumers that the product is a breakfast food and insinuates that consumers should eat it because star athletes do. Apple's "Think different" slogan entices consumers by advertising a different kind of technology product and a think-outside-the-box approach to its products.

\section{RUSSIAN ADVERTISING SLOGAN}

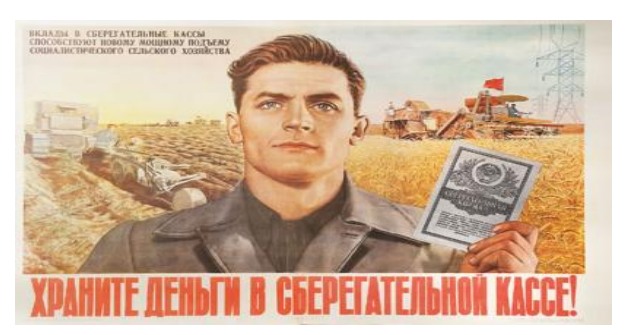

The picture above is the advertising of USSR slogan. The slogan was even said in a very popular USSR movie "Храните деньги в сберегательной кассе".. The text has communist style. The image for the slogan. The translation - "Keep your money in a savings bank". Храните - keep; деньги - money; в - in. сберегательной кассе = savings bank. Communists respect people very well. In Russian language if people want to say to a person with respect then they must add "те" to the end of the word. "Храни" = "keep" but without respect. Current advertisement treats people without respect, but soviet people treated with respect. Thus, people said "храниТE".

\section{RUSSIAN LANGUAGE}

With its host of suffixes and prefixes, and idiomatic flourishes, Russian is extremely colorful in fiction. On the other hand: (a) its words are generally longer than, say, in English; (b) its word-forming power is lower; (c) many words, especially in high technologies, can 
only be translated into Russian using two lines or so. The examples are "computing," "networking," "full-featured," "sharing," etc. In the body of a copy an experienced copywriter can handle this, but titles and headlines that include "problem" English words may look extremely cumbersome when translated. Even the nice English phrase "simply the best" will be a problem for a Russian translator. Russia is now flooded with foreign names of products that tell absolutely nothing to an average Russian. Some of the names are excellent self-explanatory sellers in English - Deep Cleanser, Head-and-Shoulders, Wash-and-Go, Handy Stitch, Coldrex, etc., etc. Admittedly, those names are a problem in other languages, but most Europeans can at least work out their meanings. For Slavs nearly all of them are double Greek. To make up for that takes some talent.

\section{RUSSIAN SLOGAN}

Some international companies come to Russia with untranslatable or meaningless slogans. The examples are galore. Nobody in Russia can properly translate Nike's "Just do it," Microsoft's, "We are rolling out the wheels." For Xerox, that pioneer of copying, we thought up and tested "We taught the world to copy." We had the Russian, Ukrainian and Byelorussia versions of the line. It was replaced by "The Document Company." In Russia, where it is used in English at that (!?), nobody can understand it. Besides, in the post-Soviet environment the phrase has a police connotation - in Russian the first meaning of the word dokumenty is ID.

\section{ADVERTISING IN RUSSIA}

The Russian advertising scene can be best described by the Biblical phrase: the blind leading the blind. Blind agencies leading blind advertisers. The quality of ads in Russia is horrible for two reasons. For one thing, most of Russian advertisers do not have the slightest idea of what good advertising is about. For the other, the same pretty much goes for Russian ad-makers (including those who man local branches of Western chain agencies). The ads they produce are all too often a waste of the client's money. Oddly enough, people stand better 
chances to find good, down-to-earth, advertising that sells not in Moscow, but in other Russia's places. One reason is that provincial agencies are not spoiled by huge ad budgets of the internationals, which is the case in Moscow. Of necessity, they have to supply the goodies to local manufacturers or retailers for their hard earned advertising monies.

\section{CULTURAL AND LINGUISTIC DIFFERENCES OF ENGLISH VERSUS RUSSIAN IN LANGUAGE ADVERTISING}

These cultural and linguistic differences have the following consequences in Englishlanguage and Russian-language advertising (Six, 2007):

1. English advertising uses many abstract words, highly abstract phrases, and incomplete constructions that can be interpreted in many ways. Thus, it is the listener who connects the advertised product and the conveyed image and, in this way, English ads involve the buyer. Ambiguity is commonly used, as in “Just do it!" In contrast, because Russian words are more concrete and descriptive, the translation of many abstract slogans is either impossible, or results in clumsy foreign-sounding language use. Russian tends to avoid incomplete sentences, since incompleteness can result in ambiguity.

2. English uses questions and imperatives to identify a situation or problem in the advertisement. In Russian, questions and imperatives are used in their primary function as interrogatives and commands. Overuse of these structures is a typical and poorly received by Russians.

3. Polysemy, homonymy, and onomatopoetic words are widely used in English slogans, product names, brand names, and other text advertising. In Russian, the use of such wordplay conceals the inner form of the word. The use of abstract, pure sound associations, such as the word Schweppes, is restricted by the tendency for the clear meaningful inner forms of words. Russians would prefer the word Rossinka, strongly associated with the word rosa. Russian uses sound forms to improve remembrance of the sentence structure and also to describe the image. Rhyme and rhythm are used more often than pure onomatopoeia. 


\section{DEFINITION OF STYLISTICS}

There are many definitions of stylistics. In Encyclopedia Britannica (2015), stylistics is the study of the devices in languages (such as rhetorical figures and syntactical patterns) that are considered to produce expressive or literary style. Meanwhile, Crystal ( : 99-100) said that stylistics is a label that covers the whole complex of varieties and styles that make up 'a' language - comprehending such differences as the distinction between written and spoken English, monologue and dialogue, formal and informal, scientific and religious, and many more. For some people, stylistics means simply 'the study of the language of literature', 'the study of the language habits of specific authors' which is rather misleding and back-to-front way of approaching the subject. It is true that the concept of 'style' is generally discussed in a literary context, and usually restricted to those linguistics features which define a single author's (or a literary group's) individuality — as when people talk of Shakespeare's style, or the style of the Romantic poets. But the dramatic, original, vivid expressions which may find in literary language is only fully interpretable if people view it against the backdrop of their everyday use of language. Literary language is language being usedin a special way; it is never (even in the most'conversational' of dramas, as in some of Pinter's plays) a faithful reflection of everyday speech, and it may depart very considerably from the grammatical and other norms of such speech (as in the example from Dylan Thomas or E.E. Cummings which linguists are so fond of citing in discussing this point). People may and do , of course, respond to literary language in a quite unconscious, direct, sensitive way, and this requires no reference to non-literary usage; but as soon as people wish to explain the basis of a literary linguist effect, either to themselves or to others, then people need to make some reference to the normal pattern of language which the author has manipulated in order to produce this effect. Stylistics in this context, is simply a technique of explication which allows people to define objectively what an author has done in his or her use of language. Other point of view of stylistics derived from Burke (2014:20). He said that stylistics, or'literary linguistics' as it is sometimes called, is the study and analysis of texts; it is in particular, although not exclusively, the study and analysis of literary texts 


\section{FEATURES OF OF LINGUISTIC STYLISTICS}

\begin{tabular}{|c|c|c|c|c|c|}
\hline $\begin{array}{c}\text { LEXIS/ } \\
\text { SEMANTICS }\end{array}$ & GRAMMAR & PRAGMATICS & $\begin{array}{l}\text { PHONETICS/ } \\
\text { PHONOLOGY }\end{array}$ & GRAPHOLOGY & DISCOURSE \\
\hline $\begin{array}{l}\text { Examining the } \\
\text { stylistic aspects } \\
\text { of a text at the } \\
\text { level of word } \\
\text { choice and } \\
\text { word meaning. }\end{array}$ & $\begin{array}{c}\text {...at the level } \\
\text { of sentence } \\
\text { structure. }\end{array}$ & $\begin{array}{l}\text {....at the level of } \\
\text { inferred meaning } \\
\text { created by social } \\
\text { context. }\end{array}$ & $\begin{array}{l}\text {...at the level of } \\
\text { word sounds. }\end{array}$ & $\begin{array}{c}\ldots \text { at the level of the } \\
\text { way the form or } \\
\text { visual appearance } \\
\text { of a text signifies } \\
\text { and shapes } \\
\text { meaning. }\end{array}$ & $\begin{array}{c}\text {...at the level of } \\
\text { a text's } \\
\text { structural } \\
\text { coherence and } \\
\text { unity as well as } \\
\text { its social, } \\
\text { cultural and } \\
\text { ideological } \\
\text { aspects. }\end{array}$ \\
\hline
\end{tabular}

\section{METHODS}

The method of the study was descriptive. Descriptive research designs help provide answers to the questions of who, what, when, where, and how associated with a particular research problem; a descriptive study cannot conclusively ascertain answers to why. Descriptive research is used to obtain information concerning the current status of the phenomena and to describe "what exists" with respect to variables or conditions in a situation (Eugene\& Christine, 2015). The subject of the study was seven Russian advertising slogan which were taken from the internet. The data was collected by using content-analysis. It consists of analyzing the contents of documentary materials such as books, magazines, newspapers and the contents of all other verbal materials which can be either spoken or printed (Kothari, 2004:110).

\section{RESULTS AND DISCUSSION}

The analysis of stylistics in this level aimed at providing a methodology of analysis which included five aspects of stylistics features:

\section{Graphology}

\section{Lexicology}

3. Syntax

4. Grammar

5. Semantics 


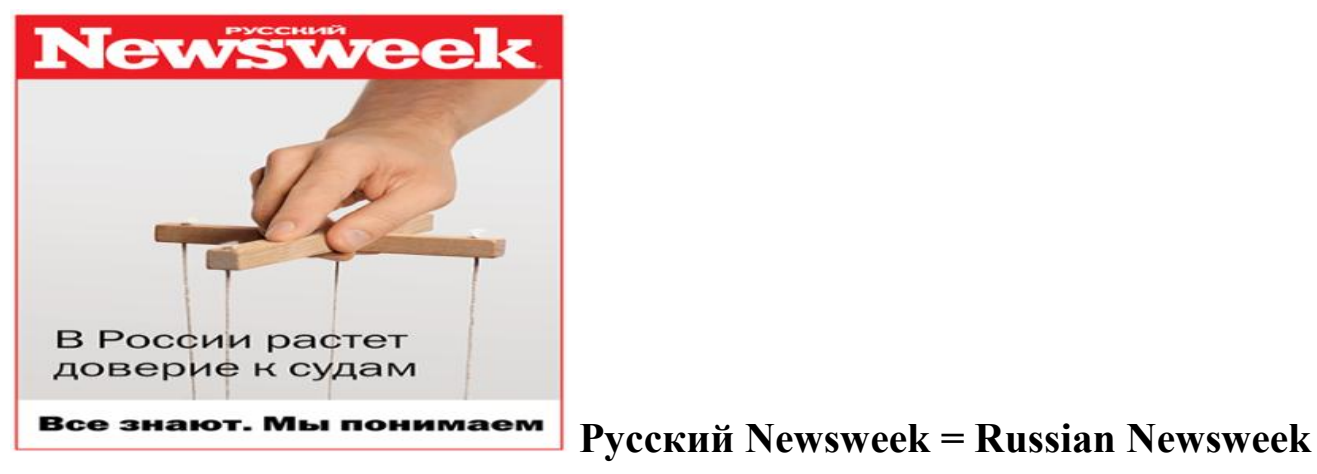

\section{The Slogan:}

Все знают. Мы понимает = Everybody knows. We understand

The Title:

В России растет доверие к судам = The trust in the Russian courts is growing

\section{Graphology}

Graphological arrangement in advertisements plays a very important role in drawing people's attention, making it outstanding among other product advertisements. The author depicted "the marionette" and wrote the words "Russian court". The readers even do not have to read the whole text because it is enough to read only the part of the phrase and look at the picture. This makes the readers curious about what this advertisement mainly says and thus leads the readers to go on reading unconsciously and arouse their curiosity and desire to know more about this product and finally reaches its goal to persuade the readers to buy it. Moreover the picture has a formal style. It means the paper is appropriate for businessmen.

\section{Lexicology}

All words used in this advertisement are of Anglo-Saxon origin. There are 4 words in the slogan and 8 words in the title. Difficult words are words which have at least three syllables, not including inflections or compounding. There are 2 difficult words in the slogan and not difficult words in the title. The percentage of difficult words in the slogan $=2 / 4 * 100$ $=50 \%$. The personal pronoun in the slogan "we" and the indefinite pronoun "everybody" are used. It means the author isolates the paper from other papers. 


\section{Syntax}

The slogan and the title contain only simple sentences because these must be short. Limited space do not allow to have complicated and long sentences. Short sentences are also easier to be remembered by the readers who are the main aim of advertising. Declarative sentences which declare facts are used. It is a kind of persuasion.

\section{Grammar}

The present tense is used because it is a newspaper. Newspapers must mirror current evidences.

\section{Semantics}

The use of rhetorical device in the advertisement is metaphor. Metaphor is an implied analogy or comparison between two unlike things that actually have something important in common. Or there is another determination - compares two things by stating one is the other. The two important things "the marionette" and "the Russian court" are unlike and are compared and the comparison may attract readers.

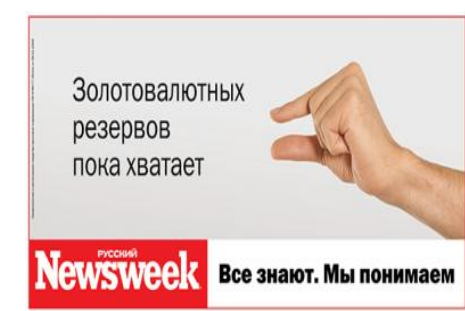

Золотовалютных резервов пока хватает $=$ The foreign exchange reserves are still enough

\section{Graphology}

This hand gesture means "small size" or "on the edge". The title of the paper has the same meaning. The picture was chosen to increase the value of the title and make readers to understand the title easily. 


\section{Lexicology}

There are 7 words in the title. There are no difficult words in the title. It means the title can be understood very easily. It is very important for advertisement.

\section{Syntax}

The title contains only simple declarative sentence.

\section{Grammar}

The present tense is used because it is a newspaper.

\section{Semantics}

The used rhetorical device in the advertisement is analogy. Analogy - compares two different things that have some similar characteristics. The hand and the title have similar characteristics.

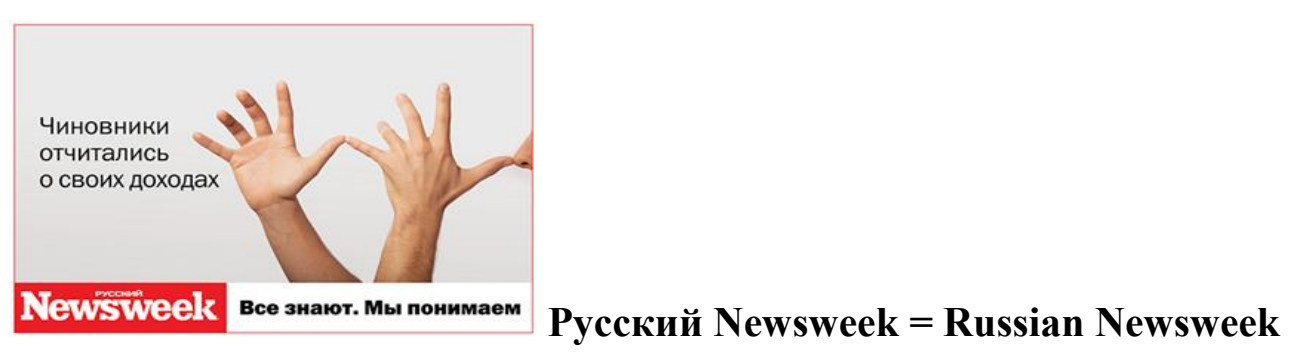

Чиновники отчитались о своих доходах $=$ The bureaucrats have reported on their income

\section{Graphology}

This hand gesture made by the bureaucrats means "teasing". It means the bureaucrats have tried to deceive. It turns the title in negative way to attract more readers. People usually like to criticize government and always curious about scandals.

\section{Lexicology}

There are 7 words in the title. There are 2 difficult words in the title. It means the title can be understood very easily. The percentage of difficult words in the title $=2 / 7 * 100=29 \%$. 


\section{Syntax}

The title contains only simple declarative sentence.

\section{Grammar}

The present tense is used because it is a newspaper.

\section{Semantics}

The used rhetorical device in the advertisement is metaphor. It compares the bureaucrats and teasing by stating one is the other.

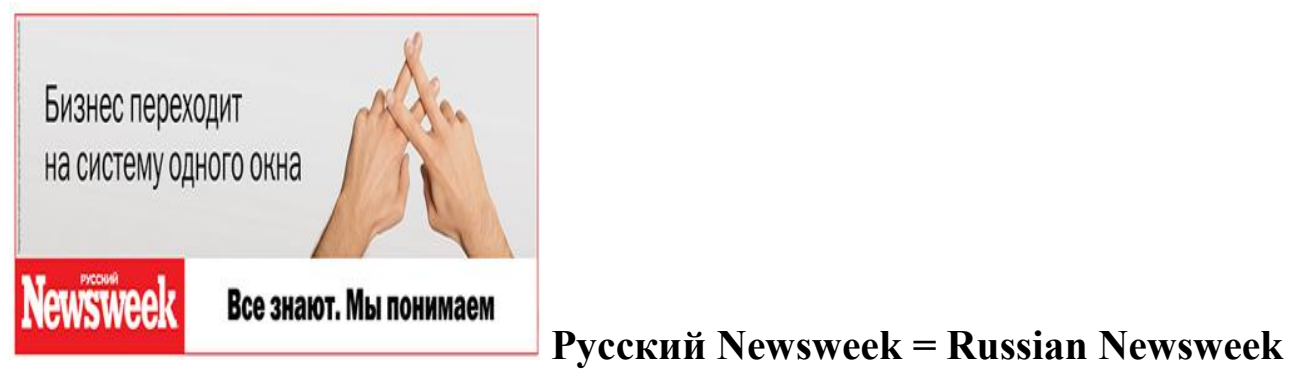

Бизнес переходит на систему одного окна = Business is switching to one-stop service

\section{Graphology}

One-stop service is a place where multiple services are offered in one window. The hand gesture also turns the meaning of the title in negative way illustrating jail. It means that the businessmen can get service in one window in a jail. Definitely, it will attract readers which like to read about crime.

\section{Lexicology}

There are 7 words in the title. There are no difficult words in the title. It means the title can be understood very easily.

\section{Syntax}

The title contains only simple declarative sentence. 


\section{Grammar}

The present tense is used because it is a newspaper.

\section{Semantics}

The used rhetorical device in the advertisement is metaphor. It compares the businessmen and jail by stating one is the other.

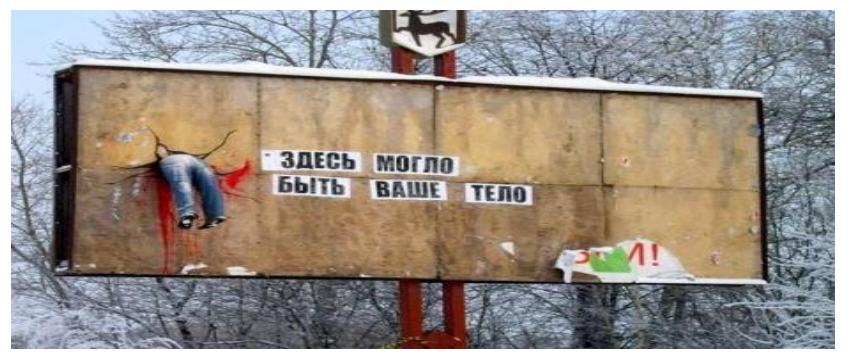

Здесь могло быть Ваше тело = Here could be your body

\section{Graphology}

The Russian word "telo" can be translated as "advertisement" and "body". The image of a dead body is illustrated to attract people's attention.

\section{Lexicology}

There are 5 words in the title. There are no difficult words in the title. It means the title can be understood very easily.

\section{Syntax}

The slogan contains only simple declarative sentence.

\section{Grammar}

The past tense is used to give people the idea that they could easily put their advertisement on the billboard. 


\section{Semantics}

The rhetorical device used in the advertisement was antiphrasis. Antiphrasis is literally the use of a word or phrase in a way that is opposite of what it really means. Here the word "telo" is used on opposite way as dead body, not as advertisement.

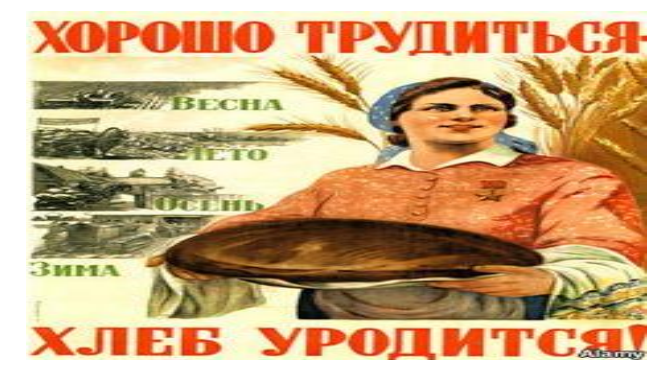

Хорошо трудиться. Хлеб уродится = Good work. Bread grows

Весна. Лето. Осень. Зима = Spring. Summer. Autumn. Winter

\section{Graphology}

If you work well then you will get good bread. A woman with big bread is illustrated to make illustration of the slogan and increase the value. In addition, work in field is illustrated during different seasons to remind people that they must work during a year to get good bread.

\section{Lexicology}

There are 4 words in the title. There are no difficult words in the slogan. It means the title can be understood very easily.

\section{Syntax}

The slogan contains only two simple declarative sentences because a slogan must be short, catchy, and easily remembered.

\section{Grammar}

The future tense is used to give people the idea that they must work well to get result in future. 


\section{Semantics}

The used rhetorical device in the advertisement is analogy. Analogy - compares two different things that have some similar characteristics. The meaning of the slogan and a happy woman with the good result of her work have similar characteristics.

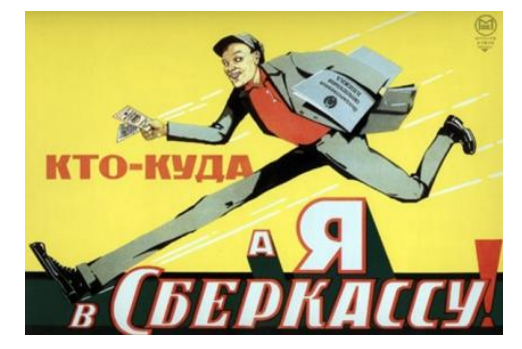

Кто-куда, а я в Сбербанк = Everybody may go anywhere but I am going to the savings bank

\section{Graphology}

The slogan means - you are free to do whatever you want, but I am going to the savings bank to save my money. The person in the advertisement is illustrated as a good example what people must do. He runs very fast. He holds lots documents. The point is that everybody must do the same. The picture increased the value of the slogan.

\section{Lexicology}

There are 12 words in the title. There are 2 difficult words in the slogan. It means the title can be understood very easily. The percentage of difficult words in the slogan = $2 / 14 * 100=14 \%$.

\section{Syntax}

The slogan contains only one simple declarative sentence because a slogan must be short, catchy, and easily remembered. 


\section{Grammar}

The present tense is used to give people the idea that they must do similar actions right now (not in future).

\section{Semantics}

The use of rhetorical device in the advertisement is analogy. Analogy - compares two different things that have some similar characteristics. The meaning of the slogan and a happy man with the documents have similar characteristics

\section{CONCLUSIONS AND SUGGESTIONS}

From the analysis and interpretation above, the stylistic features in Russian advertising slogan were clear and not ambiguous. They were conveyed the way they are. They knew their audiences well as it was shown from the advertisements above. Semantically, from one to seven advertisements, metaphor often appeared. From Lexicology, most of the words were easy to be interpret by the consumers, only in the part of law advertisement was a bit difficult. The Syntax that the advertising slogan used commonly in the form of declarative and imperative sentences. Grammar used in the advertisements contained suitable tenses with the moment shown in that ads.

The power of stylistics can also help people to understand in more depth the ways in which the style of texts can help to influence the perceptions of readers in more everyday situations, such as listening to political speeches, responding to advertisements and so on, people need stylistics because much of their lives are negotiated through language and though this language is well-described in structural terms by descriptive linguistics, and in contextual terms by such disciplines as discourse analysis and pragmatics, there remain insights about textual meaning that are addressed more effectively by a discipline which arose from literary studies, took on the apparatus of linguistics, and with the text at its core, became a powerful discipline in its own right. It is better for people who interest in analyzing the texts using stylistic to get deeper to the object. 


\section{REFERENCES}

Britannica, Science. 2015. Stylistics. Retrieved from: www.britannica.com/science/stylistics. Accessed on April, 2016.

Burke, Michael. 2014. The Routledge Handbook of Stylistics. Routledge: New York. Retrieved from: samples.sainsburysebooks.co.uk/9781317747208_sample_867390.pdf. Accessed on April, 2016.

Business Dictionary Online. __ _ _ Slogan. Retrieved from: http://www.businessdictionary.com/definition/slogan.html\#ixzz4AyM6Dx7Q.

Campsall, Steve.2014.Lingusitic Analytical Method. Englishbliz Guide. Retrieved from: http://www.englishbiz.co.uk/mainguides/a-level_frameworks.htm.

Crystal, David.__. New Perspectives for Language Studt. 1:Stylistics. Retrieved from: www.davidcrystal.com/?fileid=-4916. Accessed on April, 2016.

Damavova, Petra.2007. The Language of Law-A Stylistic Analysis with a Focus on Lexical (Binomial) Expressions. Masaryk University:Brno. Retrieved from: https://is.muni.cz/th/79361/pedf_m/THESIS.pdf.

Johnson, Roy. 2004. Stylistic Analysis-How to Do It. English Language Software Program: Mantex. Retrieved from: http://www.mantex.co.uk/2009/09/13/english-language-stylistic-analysis/.

Kothari, C.R.2004. Research methodology: Method and technique.New Age International (P) Limited, Publishers: New Delhi.

M, Eugene \& Christine E. Lynn. 2015. SOC-200 Research Methods in the Social Sciences: Descriptive Design. Lynn University. Retrieved from: http://lynn-library.libguides.com/researchmethods.

Newton, Chris.___. Slogan Advertising.Studio D: Small Business. Retrieved from: http://smallbusiness.chron.com/slogan-advertising-mean-21024.html.

Repiev, Alexander.2011. A Glimpse of Russia’s Advertising and Marketing. Russia: Moscow. Retrieved from: http://www.repiev.ru/doc/Russian-Advertising.pdf.

Simpson, Paul. 2004. Stylistics: A Resouce Book for Students. Routledge: London. Retrieved from: faculty.mu.edu.sa/public/uploads/1347486842.212825721641-stylistic-a-resource-book-for-studentspaul-simpson.pdf. Accessed on April, 2016. 
Six, Irina. 2007. What do Ads Add to the Classroom. USA:Kansas. Global Business Languages, Vol. 11: Matters of Perspectives, Article 8. Retrieved from: http://docs.lib.purdue.edu/cgi/viewcontent.cgi?article=1138\&context=gbl. 